\title{
Workers' Perception of Performance Appraisal in Selected Public and Private Organizations in Lagos Metropolis, Nigeria
}

\author{
Cyril Oseloka Ikemefuna \\ Department of Industrial Relations and Personnel Management \\ Faculty of Business Administration University of Lagos, Nigeria \\ Tel: +23-480-2304-0845; E-mail: cyikem_unilag@yahoo.co.uk \\ Christopher Odogwu Chidi (Corresponding Author) \\ Department of Industrial Relations and Personnel Management, \\ Faculty of Business Administration, University of Lagos, Nigeria \\ Tel: +23-480-2303-4213; E-mail: krischidi2002@yahoo.com
}

Accepted: July 07, 2012 Published: August 10, 2012

Doi:10.5296/ijhrs.v2i3.2221 URL: http://dx.doi.org/10.5296/ijhrs.v2i3.2221

\begin{abstract}
This study set out to examine empirically workers' perception of performance appraisal in selected public and private organisations operating in Lagos metropolis. The study adopted the survey research design. A total of 205 research subjects were drawn from the target population using the simple random sampling technique. However 174 copies of questionnaire were returned upon which the data analysis was based. This represents 85percent response rate. Data analysis was carried out with the aid of Statistical Package for Social Sciences version 16. The findings of this study showed that workers have an optimistic view of performance appraisal as a means for promoting, evaluating and equitably compensating employees, and forming the basis for many employee training programmes as well as its motivational effect on workers' performance. The authors recommend that for appraisal to yield the desired outcomes, adequate attention should be paid to the avoidance of appraisal politics and the pursuance of fairness and transparency in the process. More so, training programmes could be initiated by organisations to offer tips for avoiding appraisal errors. Open-reporting system as opposed to closed-reporting system should be encouraged for performance appraisal to have a motivational effect on workers' performance.
\end{abstract}

Keywords: Workers' Perception, Performance Appraisal, Public, Private, Performance Management, Organisations. 


\section{INTRODUCTION}

According to Manoharan, Muralidharan and Deshmukh (2009), a review of the literature shows that performance evaluation systems are criticised for failing to achieve employees' expectations. In spite of the large body of published work on the subject of performance appraisal, there are still gaps in empirical investigations of workers' perception of performance evaluation. This study attempts to fill such gaps. Performance appraisal is a key human resource management function which is viewed as a subset of performance management. Rao (2005, p.336) opines that "performance appraisal is a method of evaluating the behaviour of employees in the work spot, normally including both the quantitative and qualitative aspects of job performance". Dessler $(2008$, p.336) views performance appraisal as any "procedure that entails setting work standards, assessing employee's actual performance relative to those standards, and providing feedback to the employees with the aim of motivating him/her to eliminate performance deficiencies or to continue to perform above par". The aims of appraisal according to Fajana (2002) are three folds: appraisal entails historical review of employees' performance; it is a means for distributing rewards as well as a means for determining training and development needs.

Manoharan, Muralidharan and Deshmukh (2009) posit that performance appraisal (PA) is an important management tool to assess employees' efficiency in the workplace, and may be defined as a structured formal interaction between a subordinate and supervisor that usually takes the form of a periodic review which could be annual or semi annual to evaluate work performance. Performance appraisal is intended to engage, align, and coalesce individual and group effort to continually improve overall organisational mission accomplishment (Grubb, 2007). It provides a basis for identifying and correcting disparities in performance. Systematically, performance appraisal reviews each employee's work performance with a view to discovering the strengths and weaknesses of individuals and to identify opportunities for future skills improvement and development. Performance appraisal is a systematic way of evaluating a workers performance and his potential for development. This continuing performance and periodic evaluation helps in retraining, promotional and retaining policies.

According to Fajana (2002), performance appraisal could be formal or informal. Formal appraisal is more orderly, systematic, planned and periodical, in which separate documents exist for the formal appraisal and this is usually recorded. Whereas, informal appraisal entails subordinate's performance assessment in the normal course of work and day - to -- day relationship. Formal appraisal occurs when the contact between manager and employee is formalised, in which case a system is established to report supervisory impressions and observations of employee performance. This could be annually or semi-annually. Informal appraisal is conducted whenever a superior and subordinate feel it is necessary. This evaluation is communicated through conversation on the job or by on-the-spot examination of a particular piece of work (Peretomode \& Peretomode, 2001). According to McGregor (1957), the formal performance appraisal plans are designed to meet the following organisational and individual needs: They provide systematic judgements to back up salary increments, transfer, 
promotions, demotions or termination. Appraisal let subordinates know where they stand and needed changes that are required in their behaviour, attitudes, skills or job knowledge.

A sound performance appraisal system can be useful in improving employees' job performance, encouraging employees to express their views or to seek clarification on job duties and serving as a key input for administering a formal organisational reward and punishment systems. For performance appraisal system to be effective, it must have the following characteristics: it must be free of bias, the evaluator or rater must be objective and the method of appraisal must be fair consistent and equitable. Since performance appraisal is conducted by human beings, it is subjected to a number of errors, biases, weaknesses and pitfalls. According to Noe, Hollenbeck, Gerhart and Wright (2004), performance appraisal has been bedevilled by a lot of errors such as: Halo effect: This involves the rater giving the employee superlative or impressive rating on one factor and then using this to influence positively rating on all other factors. That is first impression is the last impression. Horns effect: This is the opposite of the halo effect. This is a rating error that occurs when the rater responds to one negative aspect by rating the employee low in other aspects. Strictness error: This is a rating error committed when the rater consistently gives employees very low ratings. Leniency error: Some raters are by nature too liberal, while others tend to be lenient in their rating of employees. Recency error: This is a tendency of many evaluators to give much more weight to the recent behaviours of the employees than past behaviour. Central tendency: It is the most commonly found error. It is the tendency of most raters to give average ratings to all employees. This may be due to the fact that a very high rating or a very low rating could invite questions, criticisms or explanations. It could also be due to the fact that the rater lacks sufficient knowledge about the employee's job performance. Errors of variable standards: This results from the use of different standards of performance in the course of rating employees' performance. Miscellaneous biases: There may be some built - in biases in the minds of the rater, based upon his/her own perception of things. For instance, a German subordinate may be rated higher because of the rater's belief that all German people are quality-oriented people. Other biases may be based on the grounds of race, sex, appearance, religion, country of origin, favouritism and nepotism. In view of the aforementioned pitfalls, many workers have perceived performance appraisal in a negative light.

Facteau and Craig (2001) observe that a number of studies conducted over the years indicate that supervisory ratings are often plagued by a host of problems including halo effect, leniency, intentional manipulations, race, gender and age biases. Based on these limitations efforts to examining alternative rating sources such as peer, subordinate and self-rating are gaining currency. Thus, for appraisal to be effective and ethically-based, the above errors should be avoided by raters. More so, appraisal system should be open and not confidential so that employees can have feedback on their performance ratings as well as their strengths and weaknesses. 
The objective of this study is to examine empirically workers' perception of performance appraisal in selected organisations operating in Lagos state, Nigeria.

The remaining part of the paper is structured as follows: In section two which is literature review, we examine the historical background to the study, theoretical underpinnings of performance appraisal as well as the conceptual issues involved. Section three x-rays the methodology of the study by reference to the study site, adopted research design, respondents, measures and analysis. In section four, the results of the study are presented with the aid of descriptive statistics. Section five focuses on discussion of findings and expresses how the findings of the study relate to the literature reviewed; whilst section six dwells on the conclusion and recommendations of the study.

\section{LITERATURE REVIEW}

Attempt is made in this section to review the historical background to the study, theoretical underpinnings and conceptual issues germane to performance appraisal. A brief historical excursion reveals that performance appraisal has a long etymology. The earliest and first known performance appraisal took place during the Wei dynasty (AD221-265) in China when the emperor engaged an imperial rater, whose task was to evaluate the performance of the official family (Koontz, 1971; Goel, 2010). "In the 16th century Ignatius Loyola established a system for formal rating of the members of the Jesuit Society" (Armstrong, 2009, p.10). The first formal monitoring system evolved out of the work of Frederick Winslow Taylor of the scientific management school. Rating for the U.S armed services was introduced in 1920. Merit rating came to the fore in the U.S and the U.K in the 1950s and 1960s respectively; and later re-christened performance appraisal. Management by objectives became popular in the U.S and the U.K in the 1960s and 1970s respectively. The term performance management gained prominence in the 1980s.

\subsection{Theoretical Framework of the Study}

This study leans on three theories of performance management. These are the social cognitive theory, goal theory and control theory (Armstrong, 2009).

\subsubsection{Social cognitive theory}

According to Armstrong (2009), social cognitive theory was developed by Albert Bandura in 1986. This theory is anchored on the concept of self-efficacy. This implies that what people believe that they can or cannot do powerfully impacts on their performance. Thus, developing positive thinking and self confidence or belief in employees could act as a boost to their performance.

\subsubsection{Goal theory}

This is credited to Lathan and Locke (1979). According to Armstrong (2009), this theory highlights four mechanisms that connect goals to performance outcomes. First, goals direct attention to priorities. Second, they stimulate effort. Third, they challenge people to bring their knowledge and skills to bear to increase their chances of success. Fourth, the more 
challenging the goal, the more people will draw on their full repertoire of skills.

\title{
2.1.3 Control theory
}

This theory centres on feedback as a determinant of behaviour. When people receive feedback on their behaviour, they are aware of the difference or divergence between their actual performance and expected performance, and then take corrective action where necessary. Thus feedback mechanism is essential in performance management.

\subsection{Concepts of Performance Appraisal and Performance Management}

According to Kandula (2011, p.5), "performance appraisal system is often confused with performance management and mostly misunderstood as synonymous. Performance appraisal is a singular activity that is employed to assess performance of employees for a predetermined duration on a set of parameters". Performance appraisal is considered one of the tools that are deployed in measuring actual performance of employees on an assigned task. Rao (2005) opines that performance appraisal is a systematic and objective way of evaluating both work-related behaviour and potential of employees. Rao further asserts that it is a process that involves determining and communicating to an employee how he/she is performing the job and establishing plans for improvement. Performance management is a systematic process for improving organisational performance by developing the performance of individuals and teams (Armstrong, 2009). According to Kandula (2011):

\begin{abstract}
Performance management is a process of designing and executing motivational strategies, interventions and drivers with an objective to transform the raw potential of human resource into performance. Performance management is viewed as an activity of goal setting and monitoring achievement of goals. (p.5)
\end{abstract}

According to Briscoe and Claus (2008), performance management is the system through which organisations set work goals, determine performance standards, assign and evaluate work, provide performance feedback, determine training and development needs and distribute rewards. From the foregoing therefore, it is clear that performance management is broader and more encompassing than performance appraisal. It is much more than appraising employees. Armstrong (2009) posits that performance management as currently practised incorporates processes such as management by objectives (MBO) and performance appraisal that were first developed long time ago; but its overall approach is significantly different. Mohrman and Mohrman (1995) argue that performance management is managing the business. It entails what line managers do on a continuous basis not an HR-directed annual procedure, but a natural process of management.

According to Muo (2007), performance appraisal entails the systematic, organised and formalised process of evaluating individual employee's job related strengths and weaknesses with a view to providing feedback on which performance adjustment can be made. Thus, performance appraisal has both evaluative and developmental objectives. It evaluates both traits and results. As noted by Armstrong (2006): 
It is sometimes assumed that performance appraisal is the same thing as performance management. But there are significant differences. Performance appraisal can be defined as the formal assessment and rating of individuals by their managers at, usually, an annual review meeting. In contrast, performance management is a continuous and much wider, more comprehensive and more natural process of management that clarifies mutual expectations, emphasises the support role of managers who are expected to act as coaches rather than judges, and focuses on the future. (p.500)

Performance management is a critical and necessary component for individual and organisational effectiveness. Without assessment and feed back, we have no basis for focusing our efforts to improve. However, when the entire process of performance management is considered, it is much more than simply evaluation and feed back (Cardy \& Leonard, 2011). Performance appraisal forms the foundation for many HR functions, effectively setting the standards to drive recruiting efforts, and it is customary to use these criteria in hiring, promoting, evaluating and equitably compensating employees, and forming the basis for many employee training programmes (Gibson, Harvey \& Harris 2007). Table 1 shows the comparisons between performance appraisal and performance management.

Table1: Performance Appraisal compared with Performance Management

\begin{tabular}{|l|l|}
\hline Performance Appraisal & Performance Management \\
\hline Top-down assessment & Joint process through dialogue \\
\hline Annual appraisal & Continuous review all the year round \\
\hline Use of ratings & Ratings less common \\
\hline Monolithic system & Flexible process \\
\hline Owned by the HR department & Owned by line managers \\
\hline Bureaucratic - complex paperwork & Documentation and paper work kept to a minimum \\
\hline Applied to all staff & Applied to all staff \\
\hline Often linked to performance pay & May not be linked to performance pay \\
\hline Focus on levels of performance and merit & Focus on development as well as performance \\
\hline Backward looking & Forward looking \\
\hline
\end{tabular}

Source: Armstrong, M. (2009). Armstrong's Handbook of Performance Management: An Evidence-based Guide to Delivering High Performance.UK: Kogan Page

\subsubsection{Conventional Methods of Performance Appraisal}

The traditional or conventional methods of performance appraisal are still widely used. Some of the traditional methods in practice are:

Essay appraisal: - The rater writes a narrative description on employee's strengths, weaknesses, past performance, potential, and suggestions for improvement. In this method, the rater simply writes a page or so about the strengths and weaknesses of the candidates and the rater's personal recommendations. 
Ranking Method: - Listing the employees in an order from higher to lowest. Only one can be best. This method simply ranks the person from "the most valuable" to the "least valuable" factors necessary for work performance. Based on the ranks of these individual characteristics, a 'key man' is created, then each worker to be rated is compared with the key man, factor by factor and a ranking of the worker is established relative to the 'key man'.

Group Appraisal Method: - This is simply the appraisal of a worker by a group of people (generally three), rather than a single rater and a general consensus or a majority decision is accepted. Even though the technique is highly time consuming, it is more comprehensive and free of bias since it involves multiple judges.

Forced Choice Method: - It is a special type of checklist and the rater has to choose between two or more statements which are more descriptive of the individual being evaluated. In this method, the rating elements are several descriptive statements including those that best fit the individual being tested and those that fit the least. The rater is forced to choose among these statements leaving no grounds to make his own statements.

Critical Incident Method: - It focuses the rater's attention on those critical or key behaviours that make the difference between doing a job effectively and doing ineffectively. The rater writes anecdotes that describe what the employee did that was especially effective or not. This is based on the principle that "there are certain acts or incidents as a result of employees' behaviour or performance which make the difference between the success and the failure". These critical incidents both good and bad are recorded so that the supervisor has some factual basis for discussions during evaluation. For example, if an employee has missed important deadlines, then this could form a basis for "unreliability". These collected incidents are then ranked in order of frequency and importance.

Checklist Method: - The evaluator uses a list of behavioural descriptions and checks off those behaviours that apply to the employee. The evaluator merely goes down the list and gives yes or no responses. This is similar to the forced choice method and lists a number of questions relating to the job and the worker which require answers in the form of Yes or No. the rater is more of a reporter. The rater indicates whether the answer to a given question is positive or negative about the given worker.

Graphic Rating Scale: - Each employee characteristic is rated on a scale that has several points ranging from poor to excellent. It assesses a person on the quantity and quality of his job performance on a variety of factors such as punctuality, leadership, initiative, dependability, decisiveness, emotional stability, maturity, coordination and co-operation. These traits are then evaluated on a continuous "scale from unsatisfactory to outstanding, where in the rater puts his mark somewhere along this scale based on his judgement of that particular trait. 
Behaviourally Anchored Rating Scales: -The appraiser rates the employees based on items along a continuum, but the points are examples of actual behaviour on the given job. These behavioural examples are then retranslated into appropriate performance dimensions.

\subsubsection{Modern Methods of Performance Appraisal}

Emerging performance appraisal methods include the 360 degree feedback mechanism, upward or reverse appraisal, potential appraisal, assessment centres and management by objectives (MBO).

\section{0-degree Appraisal:}

The 360-degree feedback appraisal entails the systematic collection of performance data and feedback on an individual or group derived from a number of the stakeholders on their performance. The data are usually fed back in the form of ratings against various performance dimensions. 360-degree feedback is also referred to as multi-source assessment or multi-rater feedback. Performance data in a 360-degree feedback process can be generated for individuals from the person to whom they report, their direct reports, their peers (who could be team members and/or colleagues in other parts of the organisation) and their external and internal customers (Armstrong, 2006). According to Brett and Atwater (2001), the 360 degree feedback appraisal mechanism is the process in which subordinates, peers, customers, and bosses provide anonymous feed back to managers on an employees' performance. The feedback on employees' activities would come from subordinates, peers, and managers in the organisational hierarchy, as well as self assessment, and in some cases external sources such as customers and suppliers or other interested stakeholders. '360'refers to the 360 degrees in a circle. Figure 1 depicts the 360-degree feedback model.

Fig.1 360-Degree Feedback Model

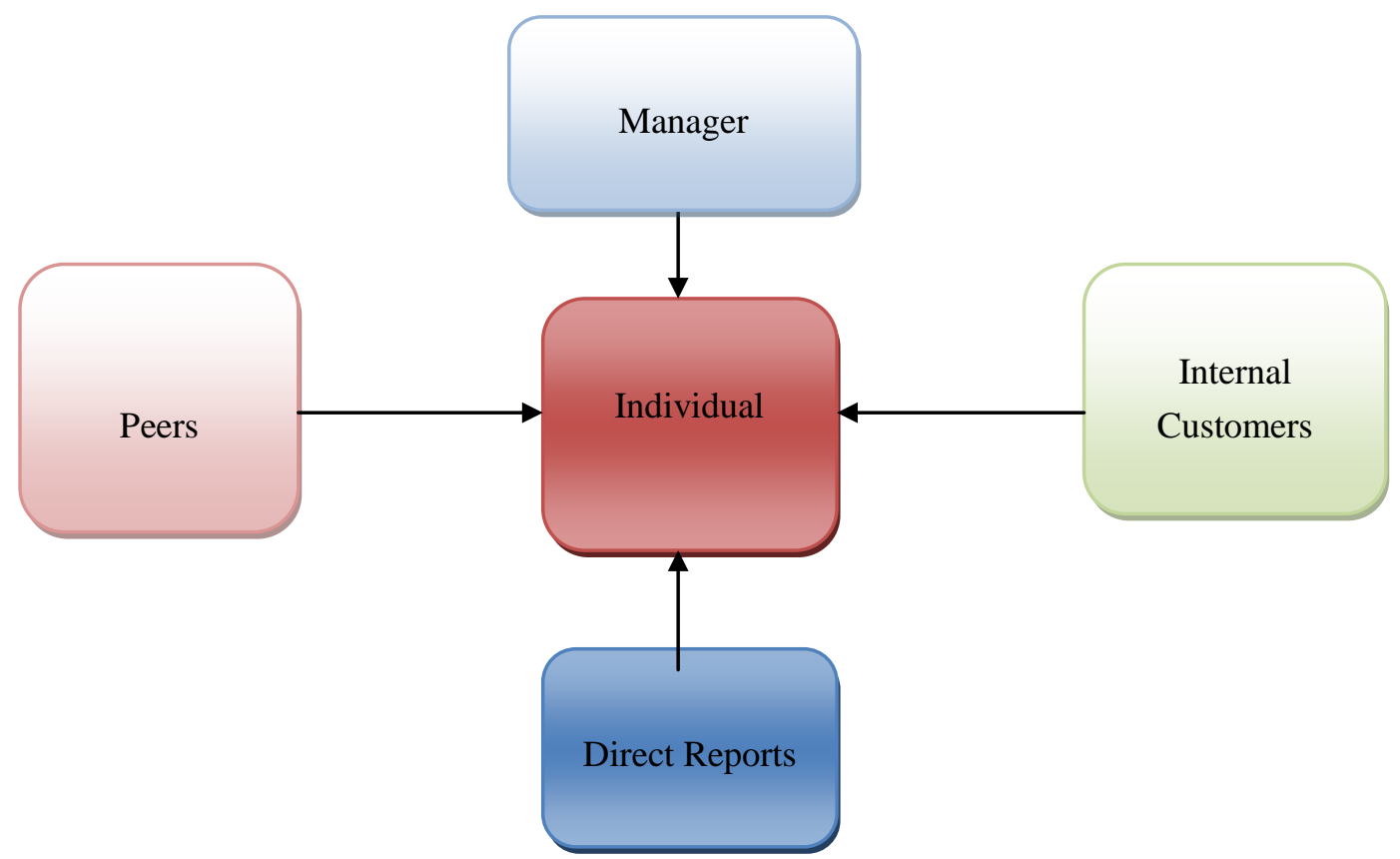

Source: Armstrong, M. (2006). A Handbook of Human Resource Management Practice. (10 ${ }^{\text {th }}$ ed.). U.K: Kogan Page Ltd. 


\section{Upward or Reverse Appraisal:}

In conventional appraisal or traditional appraisal, the superior or manager evaluates the performance of subordinates. However, in upward appraisal, subordinates are expected to assess their superiors or bosses. This method is gaining currency in some institutions of higher learning, where students complete an evaluation reports on their lecturers. According to Dessler (2008, p.361), "many employers let subordinates anonymously rate their supervisor's performance, a process called upward feedback. The process helps top managers diagnose management styles, identify potential people problems and take corrective action."

\section{Potential Appraisal:}

Besides, there is also the idea of potential appraisal. Some commentators have criticised or discredited the conventional appraisal method because too often it has been operated as a top-down and largely bureaucratic system owned by the HR department rather than by line managers. More so, performance appraisal tended to be backward looking, concentrating on what had gone wrong, rather than looking forward to future development needs. Thus, the focus of potential appraisal is to evaluate the future potentials of employees (Rao, 2005). According to Goel (2010), potential appraisal has gained currency in order to minimise the problems inherent in considering past performance as an indicator for employees' suitability to take on a higher role. The objective is to identify the potentials of the concerned employee to consider him/her for higher position in the organisational hierarchy and consequently for higher responsibility. More so, conventional appraisal views past performance as a good indicator of future job success. This is not entirely true in practice. Therefore, "to overcome this inadequacy, organisations must think of a new system called potential appraisal (Rao, 2005, p.357).

Assessment Centres: - This technique is designed to identify the managerial potential for future performance. Potential executive candidates from different departments are brought together into a common assessment centre for 2-3 days where they are given similar assignments to what they will be expected to handle at the higher positional level if they were promoted. The judgement of these activities is pooled and ranked. This continuous observation of candidates gives a much better and comprehensive ideas about their potential.

Management by Objectives (MBO): - This involves "setting specific measurable goals with each employee and then periodically reviews the progress made" (Dessler, 2008, p.353). According to Ikemefuna (2005), this is a performance appraisal method that includes mutual objective /goal setting and evaluation based on the attainment of specific objectives or goals. It divides organisational objectives into individual objectives. It seeks to measure employee performance by examining the extent to which predetermined work objectives have been met. This is a result-oriented process, rather than activity - oriented, and is based on the premise that performance can best be measured by comparison of actual results to plan or expected results. This method basically consists of the following phases: the superior and subordinate get together and jointly discuss the objectives to be accomplished during a predetermined appraisal period and the performance standards needed to reach those objectives. During the 
appraisal period, continuous communication occurs between the superior and the subordinate for frequent discussion about problems and areas of progress and if modifications are needed either in the goals or the performance standards they are made. At the end of the period, the actual results are compared with the pre-determined objectives to see if these have been met or not. If these have not been met then the causes for the deviation are traced and corrective action taken. Because the objectives are set in advance and related to the job, the appraisal is fundamentally job related, and therefore more objective. Also, the method enhances feedback, since there is periodic review of problems, resources and methods.

\section{METHOD}

The study site is the public and private sector organisations engaged in manufacturing activities, commerce/trade and services located in Lagos metropolis. The study adopted the descriptive or survey research design. There are other research designs such as observational and experimental designs. The justification for choosing the survey method is based on the fact that the study is interested in gaining an understanding of the problem being investigated without any attempt to manipulate or control the sample subjects (Asika, 1991). More so, the focus of the study is to examine the attitude or opinion of respondents as opposed to their behaviour. Primary, secondary and tertiary sources of data were utilised. An in-depth interview was carried out to corroborate some of the responses to the items in the instrument.

Respondents to the survey include management staff, senior staff, trade union officials and industrial relations and HR professionals. A total of 205 research subjects were drawn from the target population using the simple random sampling technique. However 174 copies of questionnaire were returned upon which the data analysis was based. This represents 85 percent response rate. With a view to eliciting information from respondents, a self-developed questionnaire was designed using the 5-point Likert scale ranging from strongly agree (5) to strongly disagree (1). The instrument has 22 items. Section A x-rayed the demographic profile of respondents with seven (7) items. Section B sought the views of respondents on performance appraisal in their organisation. This section has fifteen (15) items. Cronbach's Alpha or Coefficient Alpha is .60 or 60 percent. This means that the instrument is 60 percent reliable and has above average internal consistency. Data analysis was carried out with the aid of SPSS (Statistical Package for Social Sciences) version 16. Since the objective of the study is to examine empirically workers' perception of performance appraisal only descriptive statistics were deployed as opposed to inferential statistics. 
4. RESULTS

Table 2: Demographic Profile of Respondents

\begin{tabular}{|c|c|c|c|}
\hline $\mathrm{S} / \mathrm{N}$ & Variables & $\begin{array}{l}\text { Absolute } \\
\text { Frequency }\end{array}$ & $\begin{array}{l}\text { Relative } \\
\text { Frequency }\end{array}$ \\
\hline \multirow{3}{*}{1.} & $\underline{\text { Sex of Respondents }}$ & & \\
\hline & Male & 105 & $60.3 \%$ \\
\hline & Female & 69 & $39.7 \%$ \\
\hline \multirow{7}{*}{2.} & Age of Respondents & & \\
\hline & Less than 21years & 20 & $11.5 \%$ \\
\hline & $21-25$ & 44 & $25.3 \%$ \\
\hline & $26-30$ & 57 & $32.8 \%$ \\
\hline & $31-35$ & 22 & $12.6 \%$ \\
\hline & $36-40$ & 10 & $5.7 \%$ \\
\hline & 41 and above & 21 & $12.1 \%$ \\
\hline \multirow{6}{*}{3.} & Marital Status & & \\
\hline & Married & 98 & $56.3 \%$ \\
\hline & Single & 56 & $32.2 \%$ \\
\hline & Separated & 11 & $6.3 \%$ \\
\hline & Divorced & 5 & $2.9 \%$ \\
\hline & Widowed & 4 & $2.3 \%$ \\
\hline \multirow{8}{*}{4.} & Qualifications & & \\
\hline & OND & 22 & $12.6 \%$ \\
\hline & HND & 52 & $29.9 \%$ \\
\hline & First degree & 56 & $32.2 \%$ \\
\hline & Masters' degree & 35 & $20.1 \%$ \\
\hline & Ph.D & - & - \\
\hline & Professional Diploma & 5 & $2.9 \%$ \\
\hline & Others (Please specify) & 4 & $2.3 \%$ \\
\hline \multirow[t]{5}{*}{5.} & $\underline{\text { Job Category }}$ & & \\
\hline & Industrial Relations/HR Professionals & 9 & $5.2 \%$ \\
\hline & Trade union official & 37 & $21.3 \%$ \\
\hline & Senior staff & 62 & $35.6 \%$ \\
\hline & Management Staff & 64 & $36.8 \%$ \\
\hline \multirow[t]{3}{*}{6.} & Sector of respondents' organisation & & \\
\hline & Public sector & 72 & $41.4 \%$ \\
\hline & Private sector & 102 & $58.6 \%$ \\
\hline 7. & $\underline{\text { Nature of organisational activity }}$ & & \\
\hline
\end{tabular}




\begin{tabular}{|l|l|l|l|}
\hline & Manufacturing & 42 & $24.2 \%$ \\
\hline & Commercial/Trade & 58 & $33.3 \%$ \\
\hline & Service & 74 & $42.5 \%$ \\
\hline
\end{tabular}

Source: Field Survey, 2011.

Based on the analysis of data as shown in table 2, it was found that of the 174 respondents to the survey, 60.3 percent are male while 39.7 percent are female. The age bracket with the highest frequency of respondents is 26-30 years, this represents 32.8 percent. With respect to marital status of respondents, 56.3 percent is married, 32.2 percent is single, 6.3 percent is separated, 2.9 percent is divorced and 2.3 percent is widowed. With respect to qualifications of respondents, 32.2 percent of respondents have first degrees, followed by HND which represents 29.9 percent and Masters' degree with 20.1 percent. As regards job category of respondents, 36.8 percent of respondents are in the managerial cadre, 35.6 percent of respondents are senior staff, 21.3 percent are trade union officials, whilst 5.2 percent are industrial relations / HR professionals. In terms of sectoral analysis of respondents, 41.4 percent work in the public sector, whilst 58.6 percent work in the private sector. With respect to the nature of organisational activity of respondents' organisation, 42.5 percent work in service organisations, 33.3 percent work in commercial/trade organisations, whilst 24.2 percent work in manufacturing organisations.

Table 3: Descriptive Statistics of Primary Data

\begin{tabular}{|c|c|c|c|c|c|c|c|c|c|}
\hline $\begin{array}{l}\mathrm{S} / \\
\mathrm{N}\end{array}$ & STATEMENTS & $\mathrm{N}$ & SA & A & UN & $\mathrm{D}$ & SD & MIS & STD \\
\hline & & & 5 & 4 & 3 & 2 & 1 & & \\
\hline 1. & $\begin{array}{l}\text { Performance appraisal is an essential } \\
\text { tool for organisational development. }\end{array}$ & 174 & $\begin{array}{l}(83) \\
47.7 \%\end{array}$ & $\begin{array}{l}(59) \\
33.9 \%\end{array}$ & $\begin{array}{l}(9) \\
5.2 \%\end{array}$ & $\begin{array}{l}(13) \\
7.5 \%\end{array}$ & $\begin{array}{l}(10) \\
5.7 \%\end{array}$ & 4.1 & 1.16 \\
\hline 2. & $\begin{array}{l}\text { Performance appraisal serves as a } \\
\text { tool for employees' performance. }\end{array}$ & 174 & $\begin{array}{l}(66) \\
37.9 \%\end{array}$ & $\begin{array}{l}(82) \\
47.1 \%\end{array}$ & $\begin{array}{l}(12) \\
6.9 \%\end{array}$ & $\begin{array}{l}(12) \\
6.9 \%\end{array}$ & $\begin{array}{l}(2) \\
1.1 \%\end{array}$ & 4.14 & 0.90 \\
\hline 3. & $\begin{array}{l}\text { Performance appraisal has a } \\
\text { motivational effect on workers' } \\
\text { performance. }\end{array}$ & 173 & $\begin{array}{l}(18) \\
10.3 \%\end{array}$ & $\begin{array}{l}(52) \\
29.9 \%\end{array}$ & $\begin{array}{l}(41) \\
23.6 \%\end{array}$ & $\begin{array}{l}(33) \\
19 \%\end{array}$ & $\begin{array}{l}(29) \\
16.7 \%\end{array}$ & 2.98 & 1.26 \\
\hline 4. & $\begin{array}{l}\text { Performance appraisal is not an } \\
\text { essential management tool for } \\
\text { promotion. }\end{array}$ & 173 & $\begin{array}{l}(15) \\
8.6 \%\end{array}$ & $\begin{array}{l}(39) \\
22.4 \%\end{array}$ & $\begin{array}{l}(32) \\
18.4 \%\end{array}$ & $\begin{array}{l}(58) \\
33.3 \%\end{array}$ & $\begin{array}{l}(29) \\
16.7 \%\end{array}$ & 2.73 & 1.23 \\
\hline 5. & $\begin{array}{l}\text { Leadership style does not influence } \\
\text { workers perception of performance } \\
\text { appraisal. }\end{array}$ & 173 & $\begin{array}{l}(8) \\
4.6 \%\end{array}$ & $\begin{array}{l}(43) \\
24.7 \%\end{array}$ & $\begin{array}{l}(50) \\
28.7 \%\end{array}$ & $\begin{array}{l}(48) \\
27.6 \%\end{array}$ & $\begin{array}{l}(24) \\
13.8 \%\end{array}$ & 2.79 & 1.11 \\
\hline 6. & $\begin{array}{l}\text { Leadership style influences the } \\
\text { fairness of performance appraisal in } \\
\text { the organisation. }\end{array}$ & 174 & $\begin{array}{l}(25) \\
14.4 \%\end{array}$ & $\begin{array}{l}(81) \\
46.6 \%\end{array}$ & $\begin{array}{l}(21) \\
12.1 \%\end{array}$ & $\begin{array}{l}(29) \\
16.7 \%\end{array}$ & $\begin{array}{l}(18) \\
10.3 \%\end{array}$ & 3.38 & 1.22 \\
\hline
\end{tabular}




\begin{tabular}{|c|c|c|c|c|c|c|c|c|c|c|c|}
\hline 7. & \multicolumn{3}{|c|}{$\begin{array}{l}\text { Performance appraisal is used in } \\
\text { assessing employees' punctuality. }\end{array}$} & 172 & $\begin{array}{l}(26) \\
14.9 \%\end{array}$ & $\begin{array}{l}(58) \\
33.3 \%\end{array}$ & $\begin{array}{l}(44) \\
25.3 \%\end{array}$ & $\begin{array}{l}(26) \\
14.9 \%\end{array}$ & $\begin{array}{l}(18) \\
10.3 \%\end{array}$ & 3.28 & 1.20 \\
\hline 8. & \multicolumn{3}{|c|}{$\begin{array}{l}\text { Performance appraisal is used in } \\
\text { assessing employees' commitment to } \\
\text { organisational goals and objectives. }\end{array}$} & 174 & $\begin{array}{l}(48) \\
27.6 \%\end{array}$ & $\begin{array}{l}(56) \\
32.2 \%\end{array}$ & $\begin{array}{l}(35) \\
20.1 \%\end{array}$ & $\begin{array}{l}(25) \\
14.4 \%\end{array}$ & $\begin{array}{l}(10) \\
5.7 \%\end{array}$ & 3.61 & 1.20 \\
\hline 9. & \multicolumn{3}{|c|}{$\begin{array}{l}\text { Performance appraisal does not serve } \\
\text { as a fair assessment tool for workers } \\
\text { in the organisation. }\end{array}$} & 173 & $\begin{array}{l}(15) \\
8.6 \%\end{array}$ & $\begin{array}{l}(36) \\
20.7 \%\end{array}$ & $\begin{array}{l}(41) \\
23.6 \%\end{array}$ & $\begin{array}{l}(55) \\
31.6 \%\end{array}$ & $\begin{array}{l}(26) \\
14.9 \%\end{array}$ & 2.76 & 1.19 \\
\hline 10 & \multicolumn{3}{|c|}{$\begin{array}{l}\text { Performance appraisal is used for } \\
\text { training, development and training } \\
\text { needs identification. }\end{array}$} & 174 & $\begin{array}{l}(22) \\
12.6 \%\end{array}$ & $\begin{array}{l}(64) \\
36.8 \%\end{array}$ & $\begin{array}{l}(34) \\
19.5 \%\end{array}$ & $\begin{array}{l}(36) \\
20.7 \%\end{array}$ & $\begin{array}{l}(18) \\
10.3 \%\end{array}$ & 3.21 & 1.21 \\
\hline 11 & \multicolumn{3}{|c|}{$\begin{array}{l}\text { Performance appraisal serves as a } \\
\text { means for salary increment or } \\
\text { distribution of rewards. }\end{array}$} & 173 & $\begin{array}{l}(30) \\
17.2 \%\end{array}$ & $\begin{array}{l}(55) \\
31.6 \%\end{array}$ & $\begin{array}{l}(43) \\
24.7 \%\end{array}$ & $\begin{array}{l}(31) \\
17.8 \%\end{array}$ & $\begin{array}{l}(14) \\
8 \%\end{array}$ & 2.88 & 1.10 \\
\hline 12 & \multicolumn{3}{|c|}{$\begin{array}{l}\text { Performance appraisal is used as an } \\
\text { assessment tool for promotion } \\
\text { exercise. }\end{array}$} & 173 & $\begin{array}{l}(30) \\
17.2 \%\end{array}$ & $\begin{array}{l}(55) \\
31.6 \%\end{array}$ & $\begin{array}{l}(43) \\
24.7 \%\end{array}$ & $\begin{array}{l}(31) \\
17.8 \%\end{array}$ & $\begin{array}{l}(14) \\
8 \%\end{array}$ & 3.32 & 1.19 \\
\hline \multirow[t]{2}{*}{13} & \multicolumn{3}{|c|}{$\begin{array}{l}\text { Various problems affect the } \\
\text { effectiveness of performance } \\
\text { appraisal in the organisation e.g. } \\
\text { halo-effect, error of central tendency } \\
\text { and stereotype. }\end{array}$} & 171 & $\begin{array}{l}(28) \\
16.1 \%\end{array}$ & $\begin{array}{l}(71) \\
40.8 \%\end{array}$ & $\begin{array}{l}(35) \\
20.1 \%\end{array}$ & $\begin{array}{l}(24) \\
13.8 \%\end{array}$ & $\begin{array}{l}(13) \\
7.5 \%\end{array}$ & 3.45 & 1.15 \\
\hline & & & & $\mathbf{N}$ & $\begin{array}{l}\text { Annual } \\
\text { ly }\end{array}$ & \multicolumn{2}{|c|}{ Semi-annually } & \multicolumn{2}{|c|}{ Quarterly } & \multicolumn{2}{|c|}{ Not regular } \\
\hline \multirow[t]{2}{*}{14} & \multicolumn{3}{|c|}{$\begin{array}{l}\text { What is the periodicity of } \\
\text { performance appraisal in your } \\
\text { organisation? }\end{array}$} & 172 & $\begin{array}{l}(66) \\
37.9 \%\end{array}$ & $\begin{array}{l}(53) \\
30.5 \%\end{array}$ & & $\begin{array}{l}(38) \\
21.2 \%\end{array}$ & & $\begin{array}{l}(15) \\
8.6 \%\end{array}$ & \\
\hline & & & Corruption & $\begin{array}{l}\text { Favo } \\
\text { u-riti } \\
\text { sm/ } \\
\text { Bias }\end{array}$ & $\begin{array}{l}\text { Religio } \\
\text { us } \\
\text { affiliati } \\
\text { on }\end{array}$ & $\begin{array}{l}\text { Friends } \\
\text { Relatio }\end{array}$ & & Subjec & ivity & $\begin{array}{l}\text { Parti } \\
\text { mple } \\
\text { on }\end{array}$ & $\begin{array}{l}\text { /non-i } \\
\text { entati }\end{array}$ \\
\hline 15 & $\begin{array}{l}\text { What do you } \\
\text { consider the } \\
\text { problem of } \\
\text { performance } \\
\text { appraisal in } \\
\text { your } \\
\text { organisations } \\
\text { ? }\end{array}$ & 128 & $\begin{array}{l}(18) \\
10.3 \%\end{array}$ & $\begin{array}{l}(69) \\
39.7 \\
\%\end{array}$ & $\begin{array}{l}(1) \\
.6 \%\end{array}$ & $\begin{array}{l}(9) \\
5.2 \%\end{array}$ & & $\begin{array}{l}(19) \\
10.9 \%\end{array}$ & & $\begin{array}{l}(12) \\
6.9 \%\end{array}$ & \\
\hline
\end{tabular}


Based on the analysis of data as shown in table 3, it was found that of the 174 respondents, 81.6 percent agreed and strongly agreed that performance appraisal is an essential tool for organisational development. Of the 174 respondents, 85 percent agreed and strongly agreed that performance appraisal serves as a tool for employees' performance.

Fifty percent of the respondents disagreed that performance appraisal is not an essential management tool for promotion whilst 18.4 percent were indifferent. In a similar vein, eighty-five of the respondents representing 49 percent agreed that performance appraisal is used as an assessment tool for promotion exercise. Of the 173 respondents, 48.8 percent agreed and strongly agreed that performance appraisal serves as a means for salary increment or distribution of rewards.

Eighty-six out of 174 respondents which represent 49.4 percent agreed and strongly agreed that performance appraisal is used for training, development and training needs identification, whilst 19.5 percent of respondents were indifferent. With respect to performance appraisal weaknesses, 56.9 percent which is 99 out of 174 respondents agreed and strongly agreed that various problems affect the effectiveness of performance appraisal in the organisation such as halo-effect, error of central tendency and stereotype. One of the greatest challenges facing appraisal as revealed by the survey is favouritism. Of the 128 respondents to this question, 69 representing 39.7 percent indicated that favouritism is one of the problems facing appraisal in their organisation.

With regard to the periodicity of performance appraisal in respondents' organisations, of the 172 respondents to this question; 66 respondents representing 37.9 percent responded that appraisal is done annually in their organisation, 53 respondents which is 30.5 percent responded that it is carried out semi-annually, 38 respondents which represents 21.2 percent responded that it is done quarterly. Fifteen respondents which represent 8.6 percent responded that appraisal is not regular. There is an indication that appraisal is carried out in the organisations surveyed; which in some cases could be formal or informal.

With respect to the influence of leadership style, of the 174 respondents, 61 percent agreed and strongly agreed that leadership style influences the fairness of performance appraisal in their organisation. It was found that performance appraisal has a motivational effect on workers' performance and is used in assessing employees' commitment to organisational goals and objectives. Based on the in-depth interview carried out, it was found that the 360-degree feedback also referred to as multi-source assessment and the upward appraisal have not been fully adopted and diffused in respondents' organisations.

\section{DISCUSSION OF FINDINGS}

Our findings indicate that performance appraisal is an essential tool for organisational development and that performance appraisal serves as a tool for employees' performance. More so, it was found that performance appraisal is used as an assessment tool for promotional exercise. These findings corroborate the views of (Gibson, Harvey \& Harris, 2007). Our finding that performance appraisal serves as a means for salary increment or distribution of rewards is in consonance with the views of Briscoe and Claus (2008) as well 
as Fajana (2002) who hold the view that appraisal is a means for distributing rewards.

It was found that performance appraisal is used for training, development and training needs identification. This finding corroborates the views of Briscoe and Claus (2008) as well as Fajana (2002) who view appraisal as a means for determining training and development needs of employees. We found that various problems affect the effectiveness of performance appraisal in the organisations surveyed such as halo-effect, error of central tendency, stereotype and favouritism. This finding supports the views of Facteau and Craig (2001) who observed that in a number of studies conducted over the years, supervisory ratings are often plagued by a host of problems including halo effect, leniency, intentional manipulations, race, age biases and gender. Our finding on the periodicity of appraisal is consistent with the views of Peretomode and Peretomode (2001); Manoharan, Muralidharan and Deshmukh (2009) who posit that performance appraisal is an important management tool used to assess employees' efficiency in the workplace and usually takes the form of a periodic review which could be annual or semi annual to evaluate work performance.

The finding that leadership style influences the fairness of performance appraisal in respondents' organisation supports the views of Dessler (2008) who opine that upward appraisal helps top managers diagnose management styles, identify potential people problems and take corrective action. The finding that performance appraisal has a motivational effect on workers' performance and is used in assessing employees' commitment to organisational goals and objectives supports the principles of management by objective (MBO) and is consistent with the views of (Dessler ,2008). According to Dessler, MBO entails the setting of specific measurable goals with each employee and then periodically reviews the progress made. The finding also agrees with the views of Ikemefuna (2005), who posits that MBO is a performance appraisal method that includes mutual objective /goal setting and evaluation based on the attainment of specific objectives or goals.

The findings of this study are consistent with the views of Gibson, Harvey \& Harris (2007) who argue that performance appraisal forms the foundation for many HR functions, effectively setting the standards to drive recruiting efforts, and it is customary to use these criteria in hiring, promoting, evaluating and equitably compensating employees, and forming the basis for many employee training programmes

\section{CONCLUSION AND RECOMMENDATIONS}

This study set out to examine workers' perception of performance appraisal in selected public and private organisations in Lagos metropolis. A review of the literature shows that performance evaluation systems have been criticised for failing to achieve employees' expectations as a result of some inherent flaws or errors in the performance appraisal process. In view of the aforementioned pitfalls, many workers have perceived performance appraisal in a negative light. In spite of this pessimistic view, the findings of this study to a large extent have shown that workers have an optimistic view of performance appraisal as a means for promoting, evaluating and equitably compensating employees, and forming the basis for 
many employee training programmes as well as its motivational effect on workers' performance. From the foregoing therefore, the authors recommend that for appraisal to yield the desired outcomes, adequate attention should be paid to the avoidance of appraisal politics and the pursuance of fairness and transparency in the process. More so, training programmes could be initiated by organisations to offer tips for avoiding appraisal errors. All forms of discrimination and unethical practices which could jeopardise the process should be eschewed or avoided. Open-reporting system as opposed to closed-reporting system should be encouraged for performance appraisal to have a motivational effect on workers' performance.

\section{AUTHORS' INFORMATION}

Cyril Oseloka Ikemefuna is a faculty member in the department of Industrial Relations and Personnel Management, Faculty of Business Administration, University of Lagos, Nigeria. He possesses considerable experience in the theory and practice of HRM and Industrial Relations with over 15 years practical experience in the Oil and Gas industry in Nigeria. He teaches Comparative Industrial Relations, Leadership, Motivation and Productivity and Industrial Psychology. His research interests include Personnel Psychology, Performance Management and Comparative Industrial Relations. He belongs to the following professional associations, member CIPD London and member Nigerian Institute for Training and Development (NITAD) and Member NIRA

Christopher Odogwu Chidi is a faculty member in the department of Industrial Relations and Personnel Management, Faculty of Business Administration, University of Lagos, Nigeria. He possesses considerable experience in the theory and practice of HRM and Industrial Relations in the public and private sectors. He teaches courses in HRM, Industrial Relations, Research Methods, Organisational Behaviour, Industrial Psychology, Industrial Sociology and Business Communication. His research interests include Human Capital Resourcing, Employee Retention, HRM, Industrial Relations and Organisational Behaviour. He belongs to the following professional associations, Associate Member CIPMN, Associate Member Nigerian Institute for Training and Development (NITAD) and Member NIRA. 
REFERENCES

Armstrong, M. (2009). Armstrong's Handbook of Performance Management: An Evidence-based Guide to Delivering High Performance.UK: Kogan Page

Armstrong, M (2006). A Handbook of Human Resource Management Practice (10 ${ }^{\text {th }}$ ed.). U.K: Kogan Page Ltd

Asika, N. (1991). Research Methodology in the Behavioural Sciences. Lagos: Longman Nigeria Plc.

Bandura, A. (1986). Social Boundaries of Thought and Action. Englewood Cliffs, NJ: Prentice-Hall

Brett, J.F. \& Atwater, L.E.(2001). "360 Degree Feedback: Accuracy, Reactions and Perceptions of Usefulness." Journal of Applied Psychology.Vol.86 №. 5, pp.930-942

Briscoe, D. B. \& Claus, L.M. (2008). "Employee Performance Management: Policies and Practices in Multinational Enterprises". In P.W. Budwah \& A. DeNisi (eds). Performance Management Systems: A Global Perspective. Abingdon: Routledge

Cardy, R.L. \& Leonard, B. (2011). Performance Management: Concepts, Skills and Exercises. $\left(2^{\text {nd }}\right)$. New Delhi: PHI Learning Private Ltd.

Dessler, G. (2008). Human Resource Management $\left(11^{\text {th }}\right.$ ed). New Delhi: Prentice-Hall of India Private Ltd.

Facteau, J.D. \& Craig, B. (2001). “Are Performance Appraisal Ratings from Different Rating Sources Comparable?" Journal of Applied Psychology. Vol.86, N0. 2, pp. $215-227$

Fajana, S. (2002). Human Resource Management: An Introduction. Lagos: Labofin \& Company.

Gibson, S. G., Harvey R. J., \& Harris, M. L. (2007). "Holistic Versus Decomposed Ratings of General Dimensions of Work Activity”. Management Research News Journal. Vol. 30 №.10, pp. 724-734.

Goel, D. 2010). Performance Appraisal and Compensation Management: A Modern Approach. New Delhi: PHI Learning Private Ltd.

Grubb, T. (2007). "Performance Appraisal Reappraised: It's Not All Positive”. Journal of Human Resources Education, 1(1), 1-22.

Ikemefuna, C.O. (2005). Management: Theory and Practice. Lagos: Concept Publications 
Kandula, S.R. (2011). Performance Management: Strategies, Interventions and Drivers. New Delhi: PHI Learning Private Ltd.

Koontz, H. (1971). Appraising Managers as Managers. New York: McGraw-Hill

Latham, G.P. \& Locke, E.A.(1979). "Goal Setting: A motivational Technique that Works". Organisational Dynamics. Autumn, pp.442-447

Manoharan, T. R., Muralidharan, C. \& Deshmukh, S. G. (2009). "Employee Performance Appraisal Using Data Envelopment Analysis: A Case Study". Research and Practice in Human Resource Management, 17(1), 92-111.

McGregor, D. (1957). “An Uneasy Look at Performance Appraisal." Harvard Business Review. May/June

Mohrman, A.M. \& Mohrman, S.A. (1995). "Performance Management is running the Business." Compensation \& Benefit Review. July-August, pp.69-75

Muo, I. K. (2007). "Improving the Effectiveness of Performance Appraisal as an Evaluative Instrument in the Workplace."Nigerian Journal of Labour Law and Industrial Relations.Vol.1, N0.3, pp.133-146

Noe, R. A., Hollenbeck, J.R., Gerhart, B. \& Wright, P.M. (2004). Fundamentals of Human Resource Management. New York: McGraw - Hill/ Irwin.

Peretomode, V.F \& Peretomode, O. (2001). Human Resources Management: Principles, Policies and Practice: Lagos: Onosomegbowho Ogbinaka Publishers.

Rao, V.S.P (2005). Human Resource Management: Text and Cases. (2 ${ }^{\text {nd }}$ ed.). New Delhi: Excel Books. 